\title{
Recenzja książki Michała Wojciechowskiego, Dwie wersje Dziejów Apostolskich. Tekst standardowy i zachodni, Kraków 2018, ss. 175
}

Biblia, zanim powstała, przeszła długą drogę od tradycji ustnej przez wstępne spisanie aż po ostateczną redakcję. Przyjmuje się, że tradycja ustna Biblii swymi korzeniami sięga XVIII wieku przed Chrystusem. Przyjmuje się także, że księgi Starego Testamentu wstępnie pisano, a następnie redagowano między X a I wiekiem przed Chrystusem, z kolei teksty Nowego Testamentu - pomiędzy 51 a 120 rokiem po Chrystusie. Zakłada się więc, że powstawanie Pisma Świętego nie było jednorazowym aktem, lecz dynamicznym procesem rozłożonym na blisko tysiąc lat. Koniecznie należy wiedzieć, że Kościół potrzebował jeszcze blisko trzech stuleci, by zbadać autentyczność poszczególnych ksiąg Biblii i sprawdzić ich teandryczne pochodzenie. Nieodzownie należy wiedzieć także, że czas ten obfitował w liczne dramatyczne zwroty akcji. Już bowiem w II wieku zaczęto kwestionować natchniony charakter czternastu ksiąg biblijnych, a mianowicie: siedmiu ksiąg Starego Testamentu (Ba, Tb, Jdt, Syr, Mdr, 1 Mch i 2 Mch) oraz siedmiu ksiąg Nowego Testamentu (Hbr, Jk, 2 J, 3 J, 2 P, Jud i Ap). Na przełomie zaś III i IV wieku prawie powszechnie zaczęto uznawać je za nienatchnione i odradzano umieszczania ich w kanonie Biblii chrześcijańskiej. Gdyby więc nie Dekret Gelazego (380 r.) i List papieża Innocentego I (405 r.), które uznały natchniony charakter wyżej wymienionych ksiąg, z pewnością wszelki ślad po nich by zaginą. $Z$ tego jednak względu, że wspomniane Dokumenty uznały teandryczne pochodzenie tych zapisów, Biblia katolików liczy dziś 73 księgi, z czego 46 to księgi Starego Testamentu, a 27 to pisma Nowego Testamentu.

Wydawać by się mogło, że sprawa kanonu biblijnego została raz na zawsze zamknięta. Jednak do dziś toczą się spory wśród egzegetów o to, czy w Kościele katolickim - i nie tylko katolickim - czczone są właściwe wersje poszczególnych ksiąg biblijnych, czy z wielu starożytnych wariantów tej samej księgi, wybrano tę właściwą. Bibliści bowiem nadal zastanawiają się, czy trafnie z wielu wariantów wybrano na przykład wersję Księgi Jeremiasza, Ewangelii Marka czy Dziejów Apostolskich. W gronie zaś egzegetów, którzy przyłączyli się do tej ciągle nierozstrzygniętej - dyskusji, znalazł się również prof. dr hab. Michał 
Wojciechowski, Autor opiniowanej książki: Dwie wersje Dziejów Apostolskich. Tekst standardowy i zachodni, która nakładem Wydawnictwa Petrus ukazała się w Krakowie w 2018 roku.

Już z tytułu książki wynika, że Autor objął badaniami wyłącznie Księgę Dziejów Apostolskich, że poddał analizie dwa jej warianty, a mianowicie: zapis oficjalnie przyjęty przez Kościół, który nazwał standardowym, oraz tekst zachodni reprezentowany przez Kodeks Bezy. Swoją zaś publikację podzielił na dwie części, które zatytułował: Wprowadzenie (ss. 9-26) oraz Dwa równoległe teksty Dziejów Apostolskich — Przekład i noty (ss. 27-175). Warto im się przyjrzeć.

Pierwszą część książki (ss. 9-26) prof. Wojciechowski poświęcił zagadnieniom introdukcyjnym, w syntetyczny sposób omawiając wyżej wspomniane wersje Dziejów Apostolskich. Najpierw wprowadził w lekturę wersji oficjalnej, którą odnotowano w takich starożytnych rękopisach, jak na przykład: Kodeks Synajski (S, 01; IV w.), Watykański (B, 03; IV w.) czy Aleksandryjski (A, 02; V w.), oraz we współczesnym wydaniu Novum Testamentum Graece (red. Nestle-Aland). Następnie opisał wersję zachodnią, reprezentowaną przez Kodeks Bezy (D, 05; $\mathrm{V}$ w.) $)^{1}$. W trakcie zaś tych prezentacji uwypuklił, że egzegeci zapis oficjalny (= standardowy) określili mianem „krótszego”, a tekst zachodni — „dłuższego”. Wyjaśnił, że uczynili to dlatego, że porównując poszczególne greckie stychy obu wersji Dziejów Apostolskich, z łatwością dostrzegli, iż w wersetach odnotowanych w Kodeksie Bezy zachodzą liczne dodatki, uzupełnienia i dopowiedzenia, które rozbudowały ten tekst o $8 \% \mathrm{w}$ stosunku do zapisu oficjalnego (= standardowego). Jednak Autor recenzowanej książki przestrzegł przed nieumiejętnym posługiwaniem się określeniami: „zapis krótszy”, „tekst dłuższy”. Podkreślił bowiem, że w wersję oficjalną Dziejów Apostolskich wchodzi 28 kompletnych rozdziałów, podczas gdy w wariancie zachodnim pojawiają się liczne braki. Z Kodeksu Bezy zginęło bowiem 66 kart, na których odnotowane były greckie zapisy Dz 9 oraz Dz 23-28. Prof. Wojciechowski udobitnił więc, że wersja dhuższa (= zachodnia) nie do końca jest dłuższą. Dalej, Autor recenzowanej książki dowiódł, że obydwa teksty Dziejów Apostolskich, zarówno standardowy, jak i zachodni, są dziełem tego samego pisarza - oczywiście Łukasza. Orzekł nawet, że to Łukasz - a nie jakiś anonimowy kopista - wprowadził wszystkie poprawki i uzupełnienia do wersji nazywanej zachodnią. Zauważył bowiem, że wszystkie one zdradzają jego ,pióro”: jego słownictwo, styl i składnię. Pod koniec pierwszej części swojej książki prof. Wojciechowski podjął próbę wyjaśnienia powodu powstania obu wersji Dziejów Apostolskich. Zauważył więc, że Łukasz, napisawszy Dzieje Apostolskie, sporządził również identyczną ich kopię dla siebie. Gdy zaś przekazał oryginalną wersję Dziejów młodemu Kościołowi,

${ }^{1}$ Koniecznie należy pamiętać, że w Kodeksie Bezy Dzieje Apostolskie zostały odnotowane zarówno w języku łacińskim, jak i greckim. 
a ten zaczął się nad nią pochylać, modlić i medytować, on sam dalej pracował nad kopią Dziejów, którą zatrzymał dla siebie, nanosząc na nią liczne poprawki stylistyczne i rzeczowe, wydłużając w ten sposób pierwotną wersję swojej księgi. I tak oto sukcesywnie dzień po dniu powstawała druga wersja Dziejów Apostolskich. Nie trzeba chyba dodawać, że po śmierci Łukasza anonimowi skrybowie przepisywali obie te wersje - zarówno oryginalną (= „krótszą"), jak i jej kopię (= „dłuższą") - a ich prace - oczywiście nie wszystkie — przetrwały do naszych czasów. Kościół zaś, wybierając pomiędzy tymi wersjami, za tekst oficjalny wybrał - lepiej udokumentowany — pierwotny zapis Dziejów (= krótszy) i wprowadził go do kanonu Biblii.

Z kolei w drugiej części swojej książki (ss. 27-175) prof. Wojciechowski zaprezentował na sposób synopsy obydwa warianty Dziejów Apostolskich, a mianowicie w lewej kolumnie umieścił tekst oficjalny (= standardowy), w prawej zaś zachodni (= Kodeks Bezy). Koniecznie należy podkreślić, że zapisy te przytaczał w języku polskim - we własnym thumaczeniu — podzieliwszy je uprzednio na perykopy, pod którymi umieszczał naukowy komentarz. Nieodzownie należy również dodać, że passusy te zapisał jednolitą czcionką tylko tam, gdzie były one identyczne w obu wersjach. Gdy natomiast w tekście zachodnim zachodziły choćby najdrobniejsze różnice stylistyczne w stosunku do wariantu standardowego, zawsze zapisywał je kursywą, a wszelkie dodatki i uzupełnienia - wytłuszczonym drukiem. By to zilustrować, warto przytoczyć trzy przykłady. Oczywiście, by ,nie rozsadzić” ram niniejszej publikacji, nie zostaną przytoczone całe perykopy, lecz jedynie pojedyncze stychy, a mianowicie: Dz 12,25; 13,42 oraz 18,4:

\begin{tabular}{|c|c|}
\hline Tekst oficjalny (= standardowy): & Tekst zachodni: \\
\hline $\begin{array}{l}\text { Zaś Barnaba i Saul wrócili ku Jeruzalem, } \\
\text { wypełniając zadanie, zabrawszy ze sobą } \\
\text { Jana zwanego Markiem (Dz 12,25). }\end{array}$ & $\begin{array}{l}\text { Zaś Barnaba i Saul wrócili ku Jeruzalem, } \\
\text { wypełniając zadanie, zabrawszy ze sobą } \\
\text { Jana zwanego Markiem (Dz 12,25). }\end{array}$ \\
\hline $\begin{array}{l}\text { A kiedy oni wychodzili, proszono, żeby } \\
\text { w następny szabat przemówili do nich } \\
\text { tymi słowami (Dz 13,42). }\end{array}$ & $\begin{array}{l}\text { A kiedy oni wychodzili, proszono, żeby } \\
\text { w przyszty szabat przemówili do nich } \\
\text { tymi słowami (Dz 13,42). }\end{array}$ \\
\hline $\begin{array}{l}\text { Rozprawiał zaś w synagodze w każdy } \\
\text { szabat, przekonywał i Judejczyków, } \\
\text { i Greków }(\text { Dz } 18,4) \text {. }\end{array}$ & $\begin{array}{l}\text { A przybywając do synagogi rozprawiał } \\
\text { w każdy szabat, wymieniając imię Je- } \\
\text { zusa Mesjasza, i przekonywał nie tylko } \\
\text { Judejczyków, ale i Greków (Dz 18,4). }\end{array}$ \\
\hline
\end{tabular}

Podsumowując niniejszą recenzję, należy stwierdzić, że opiniowana książka Dwie wersje Dziejów Apostolskich. Tekst standardowy i zachodni to nietuzinkowa publikacja naukowa, jej Autor zaś - prof. dr hab. Michał Wojciechowski to doskonały egzegeta, świetnie władający piórem, piszący językiem jasnym, prostym i komunikatywnym. 
Nie pozostaje więc już nic innego, jak tylko zachęcić do lektury recenzowanej książki. A polecić ją można i specjalistom (teologom, biblistom), i niespecjalistom (studentom teologii i zwykłym miłośnikom Biblii). Ubogaci ona bowiem warsztat naukowy tych pierwszych, a pogłębi wiedzę na temat Dziejów Apostolskich tych, którzy dopiero ją zdobywają.

\section{Jarosław Ćwikła}

Prymasowski Instytut Kultury Chrześcijańskiej w Bydgoszczy

2 Dr Jarosław Ćwikła - teolog biblijny, wykładowca biblistyki, absolwent Podyplomowych Studiów Teologicznych na Wydziale Teologicznym Uniwersytetu im. Adama Mickiewicza w Poznaniu (1997-2001) oraz Podyplomowych Studiów Pedagogicznych dla teologów także na WT UAM w Poznaniu (2004-2005); e-mail: drjaroslaw.cwikla@gmail.com. ORCID: 0000-0002-43251462. 